\title{
More experienced professors, more learning opportunities? Relationships between instructor's traits and students' academic performance in financial accounting courses of a Spanish University*
}

\author{
Carmen-Pilar Martí-Ballester ** \\ Received: June 2, 2017 \\ Sent to peer reviewers: June 29, 2017 \\ Approved by peer reviewers: August 4, 2017 \\ Approved by Editorial Board: September 28, 2017 \\ DOI: $10.22395 /$ csye.v6n12a2
}

\section{ABSTRACT}

The main objective of this paper is to analyse how the characteristics of professors affect students' academic performance. To do so, we analyse a sample of recollected data from 3219 students and twelve professors from the Universitat Autònoma de Barcelona. A linear regression model, adopting the censored least absolute deviations model, was applied. Results indicate that the quality of teaching and the publication of a greater number of articles in indexed journals in the ISI
Web of Science and Econlit databases have a positive and significant influence on students' academic performance. On the contrary, dedicating more lecture time to the subject of Financial Accounting in comparison with the total amount of lecture time, working as an adjunct professor and teaching experience negatively influence students' academic performance.

Keywords: academic performance, instructor, undergraduate, censored least absolute deviations model.

This article is the result of a research process at the university context, and it was reviewed by the language service of the Universitat Autònoma de Barcelona.

** Associate professor in the Business Department at the Universitat Autònoma de Barcelona. Since September $30^{\text {th }} 2011$, she has been Secretary of the Centre for Studies and Research in Humanities, an institution associated to the Universitat Autònoma de Barcelona. Her research focuses on analyzing the financial and social performance of mutual funds, pension funds and firms. She also does research about students' academic performance. Her research papers have been published in Management Decision, Journal of Cleaner Production, Corporate Social Responsibility and Environmental Management, Revista de Estudios de Economía, Applied Economics, Educación XX1, and RBGN-Review of Business Management, among others. She is a referee for Studies in Higher Education, Business Ethics: A European Review, Sustainability, Journal of Cleaner Production, Management Decision, Corporate Social Responsibility and Environmental Management, Applied Economics, Applied Financial Economics, Applied Economics Letters, European Journal of Operational Research, Journal of Pension Economics and Finance, and Journal of Economic Interaction and Coordination, among others. She is a member of Financial Management Association International. Email: carmenpilar.marti@uab.cat 


\section{¿Profesores con más experiencia suponen mayores oportunidades de aprendizaje? Relación entre las características de los profesores y el rendimiento académico de los estudiantes en la asignatura de Contabilidad Financiera de una universidad española}

\section{RESUMEN}

El objetivo del presente trabajo es analizar cómo las características del profesor influyen en el resultado académico del alumno. Con este fin, se emplea una muestra que integra información sobre 3.219 alumnos y 12 profesores de la Universitat Autònoma de Barcelona. Dichos datos se analizan adoptando un modelo de regresión lineal sobre el que se aplica el estimador de desviación absoluta mínima censurada (CLAD). Los resultados obtenidos indican que la calidad de la docencia y la publicación de artículos en revistas indexadas en las bases de datos ISI Web of Science y Econlit tienen un efecto positivo y significativo en el resultado académico del alumno. Por el contrario, concentrar la docencia en una única asignatura, trabajar como profesor asociado y ser profesor de amplia experiencia influyen negativamente en el desempeño académico del alumno.

Palabras clave: desempeño académico, profesor, alumno, estimador de desviación absoluta mínima censurada.

\section{Professores mais experientes, mais oportunidades de aprendizagem? Relações entre as características do instrutor e o desempenho acadêmico dos alunos em cursos de contabilidade financeira de uma universidade espanhola}

\section{RESUMO}

O objetivo principal deste trabalho é analisar como as características dos professores afetam o desempenho acadêmico dos estudantes. Para isso, analisamos uma amostra de dados coletados de 3.219 estudantes e 12 professores da Universitat Autònoma de Barcelona. Foi aplicado um modelo de regressão linear que adotou o modelo de desvios absolutos mínimos censurados. Os resultados indicam que a qualidade do ensino e a publicação de maior quantidade de artigos em revistas indexadas nas bases de dados da ISI Web of Science e da Econlit têm uma influência positiva e significativa no desempenho acadêmico dos estudantes. Pelo contrário, dedicar mais tempo de conferência ao assunto de Contabilidade Financeira em comparação com a quantidade total de tempo de conferência, trabalhar como professor adjunto e considerar a experiência de ensino influenciam negativamente o desempenho acadêmico dos estudantes.

Palavras chave: desempenho acadêmico, estudante universitário, instrutor, modelo de desvios absolutos mínimos censurados. 


\section{Introduction}

International literature has documented the significance of individual students' characteristics and institutional characteristics in explaining students' academic performance in Higher Education (Cantwell et al., 2001; Marcenaro \& Navarro, 2007; Martí, 2012; McKenzie \& Schweitzer, 2001; Sheard, 2009). Even though the influence of prior academic achievement, receiving grants, effort made by the student, and student's maturity level on students' academic performance has been studied in previous work, few attempts have been made to examine the effect of professors' characteristics on students' academic success.

In this sense, one of the factors that may explain students' academic performance is the quality of teaching provided by the instructor. Thus, several authors (Marsh \& Hattie, 2002; Stack, 2003; Gibbs \& Coffey, 2004; Arnold, 2008; García-Gallego et al., 2012) have used teaching evaluations as a good indicator of teaching quality. However, student's evaluations of teaching, apart from being influenced by teacher performance, are affected by other factors such as (1) the size of the class (Bedard \& Kuhn, 2008); (2) the expected grade in the course (Ewing, 2012); (3) class grades (Beleche et al., 2012); and (4) the teaching method applied (Carrell \& West, 2010). This has prompted Angrist and Lavy (2001), Harris and Sass (2011) and Dobbie (2011) to use students' academic performance to examine teaching quality.

According to García-Gallego et al. (2012), this effectiveness could also be influenced by teaching load. Besides, these authors find that the fewer instruction hours, the higher teaching quality, and thus the higher students' performance. On the contrary, the higher teaching hours by the professor, the lower teaching quality, and thus, lower students' performance. However, this result could be biased since the authors do not include instructor rank, since some of the instructors in their sample are part-time non-tenure-track professors who may have a significant negative effect on the students' academic performance, compared to recruitment of full-time faculty members (in tenure-track and non-tenure-track positions) as shown by Jacoby (2006) and Jaeger and Eagan (2011).

This could be due to: (1) The different training levels of full-time and parttime professors. According to Benjamin (2003), the percentage of doctorate professors among full-time professors is higher than the percentage of doctorate professors among part-time professors; (2) The shorter amount of time professors are available to interact with students, and implement changes in their teaching methods, according to Benjamin (2002) and Umbach (2007); (3) The lack of motivation of this group of professors, who earn much lower salaries than fulltime professors, according to Jacoby (2005); (4) The inefficiency of the subject coordinators to assign teaching hours to subjects related to the development of 
skills in a particular occupation, according to Bettinger and Long (2010).

The productivity of faculty work differs depending on the ranks of full-time instructors, due to the learning and experience effect; in this sense, higher-rank faculty members should lead to greater productivity than those of lower ranks, as shown by Tien and Blackburn (1996). However, according to the lifecycle theory of faculty work, instructors make more effort during the first years of their academic careers, when promotion and tenure decisions are imminent; this decreases after promotion or when they are near retirement, as suggested by Levin and Stephan (1991), Goodwin and Sauer (1995), Hu and Gill (2000), Kim (2003) and Hardre et al. (2011). Therefore, students attending classes given by faculty members of lower rank could obtain higher grades than those who attend classes given by faculty members of higher rank, given that the former make more effort.

As mentioned above, instructors who are expecting to be promoted could make a greater effort to increase their productivity in the areas in which they will be evaluated: teaching, research and service (Fairweather, 2002; Marsh \& Hattie, 2002; Fogarty, 2004; Hardre et al., 2011). Considering these there areas, the Spanish State System and Spanish universities give greater weight to institutional accreditation and to the evaluation of research by individual Faculty members (García-Gallego et al, 2012) as it is the case in other countries such as Australia, the United Kingdom, and the United States (Adler \& Harzing, 2009; Bazeley, 2003; Watty et al., 2008; Mishra \& Smith, 2012; Hemmings \& Kay, 2008; Armstrong \& Goodyear, 2006; Sykes, 2006; Prince et al., 2007).

The most important rewards for instructors (tenure, promotion and professional status) go to faculty members who publish their findings in the most prestigious journals. For this reason, Faculty members seeking to be more productive in research may make less effort in their teaching activities (Barnett, 1992; Chow \& Harrison, 1998; Hardre et al., 2011; Hattie \& Marsh, 1996; Massy \& Wilger, 1995), which may have a negative influence on the academic performance of students.

In contrast, some authors such as Braxton (1996), Ramsdem and Moses (1992), Neumann (1992) and Sullivan (1996), from a conventional wisdom theory perspective, state that research productivity and teaching effectiveness are complementary because they involve common values. Furthermore, instructors who are active researchers are more organized, have more interest in learning and a greater ability to motivate students, and teach the latest developments in their discipline, which could have a positive effect on their students' academic performance. A similar conclusion is reached by García-Gallego et al. (2012) and Witte et al. (2013) who find synergies and economies of scope between 
research and teaching activities, taking as a reference the modern theories of the firm developed by Spiller and Zelner (1997), Lindbeck and Snower (2003) and Cherchye et al., (2008). However, these authors do not take into account the levels of the courses that the lecturers are teaching, which could affect their findings according to Noser et al. (1996), who find evidence of a positive but minor effect of research on teaching at undergraduate level, while mixed results appear for the graduate level.

The instructor's gender could influence teaching effectiveness for, as commented by Toutkoushian and Bellas (1999), women spend more time on teaching activities and less time on research than their male workmates, maybe because women: (1) Have greater interest in teaching; (2) Use more labor-intense teaching strategies; (3) Have heavier teaching loads; And/or (4) spend more time on course preparation than men, which could be of benefit to their students. However, these differences could be attributable to the different distribution of sexes across diverse academic ranks, as suggested by Ramsdem (1998). On the other hand, instructors of the same gender as their students could positively influence the latter's academic performance due to the Pygmalion effect or to the role-model effect as suggested by Cho (2012).

Taking into account that different factors could affect teaching effectiveness and therefore students' academic performance, the purpose of this study is to analyse whether professors' characteristics determine university students' success/failure in the subject of Financial Accounting. Thus, we seek to make two contributions to the previous literature. Firstly, we focus on a graduate accounting course, which has received little attention in education literature, despite being important to the accounting profession and to universities (it is a compulsory subject for all business program undergraduates). Secondly, while prior research tends to focus on analysing professors' productivity, we provide empirical evidence of how professors' productivity in different tasks affects the students' academic performance. The findings from this study could provide new insight for administrators and subject coordinators in terms of identifying those aspects that enable them to distribute efficiently human resources in order to improve learning environments. Better making-decisions processes in these issues might improve students' academic performance.

\section{Data and method}

\section{Institutional context}

This study was performed at a large-sized public research university (approximately 46,000 students, of which 29,018 are graduate students) in Spain. 
It is one of the most important Spanish universities according to QS World University Rankings. The institution is co-educational (60\% women; $40 \% \mathrm{men}$ ) and comprises predominantly domestic students (approximately 90\%). All students commute to the Faculty.

\section{Course description}

Financial Accounting is a compulsory undergraduate course taught in the Economics and Business Faculty for the degrees of Economics, Business, and Business and Law at Spanish universities. Thus, approximately $50.36 \%$ of the students enrolled in Financial Accounting are majoring in Economics, while 41.78 \% major in Business Studies, and 7.86\% do a Business and Law Major. The course is designed to provide students with the skills and competences needed to prepare financial statements.

To this end, students are divided into eight sections of Financial Accounting. Students must attend the assigned class and cannot make any changes during the course, thereby preventing problems of self-selection. Each class is 75 minutes long, three times a week, during a 32-week academic year. The Financial Accounting course consists of lectures with PowerPoint presentations in parallel with textbooks and exercises which are modified as the accounting laws change. Homework, examinations and the grading structure are constant throughout the eight sections of the course.

Requirements for the course include six exams, i.e., four multiple-choice exams (11.25\% each one) and two practical exams (22.5\% each one) given at the end of each semester, and homework (10\%).

\section{Sample}

The data applied derives from the Students Records Service of the Universitat Autònoma de Barcelona for eight sections of Financial Accounting from 2005 to 2009. This eliminates possible problems associated with data provided by students, as pointed out by Becker and Powers (2001). We have complete information for 3219 of the 3317 students enrolled in the course at the end of each academic year. Missing data correspond to international students for whom we do not have university entrance exam grades and student withdrawals from the course prior to the end of the academic year.

For each student we obtained information regarding their academic performance in Financial Accounting class at the end of the academic year, the program they are studying, the group in which they are enrolled, whether the student receives a grant or not, the professor responsible for the group, number 
of times the student has enrolled in the subject; student's gender, university entrance exam grade, date of birth, pre-university studies specialization and the teaching strategy for these groups.

For each instructor, we collected information regarding gender, number of years working in the university system, number of years devoted to administrative duties, total number of articles published in indexed journals, non-indexed journals and books; rank (assistant professor, associate professor, full professor or adjunct lecturer), workload in the subject of Financial Accounting and in other subjects, and the students' evaluations of their teaching.

\section{Measures}

\section{Dependent variable}

This study employs the weighted average score as a dependent variable (AP), which enables us to avoid the aggregation effect (Kennedy \& Siegfried, 1997), and address concerns about error in measurement as a result of relying on the score of one exam (Walstad, 2001). Thus, we assign a weight of 0.1125 to each of the four multiple-choice tests taken during the year; the weight of two exams taken at the end of each semester is 0.225 and the weight of the homework completed during the year is 0.1 . The maximum number of points a student could earn on each test, exams and homework is 10 , while 0 is the minimum number of points. The overall final grade obtained by each student oscillates between 0 and 10 points. The test, homework, exams and other teaching and learning materials are exactly the same in all classes, which ensures the validity of their outcome measure.

\section{Independent variables}

The independent variables comprise the focus of the analysis, which could be closely related to students' learning processes. Thus, in order to examine the effect of the professors' characteristics on students' academic performance, we use eight explanatory variables which refer to the distribution of the faculty tasks. The first of these variables refers to the administrative duties (admduties), which will take a value of 1 , if the instructor carries out administrative tasks during the academic year and 0 if not. In this line, different authors, including Toutkoushian and Bellas (1999) and García-Gallego et al. (2012), consider that administrative duties could affect teaching effectiveness and, therefore, students' academic performance. Nevertheless, in Spain, professors serving in administrative positions have a mandatory reduction in their teaching load, so it is unlikely that such positions will influence students' academic performance. 
The teaching load can also vary depending on the instructor's rank in the university, as pointed out by García-Gallego et al. (2012). Thus, adjunct lecturers, who work as part-time instructors, may feel unmotivated to teach because they earn lower salaries than full-time professors, and this may negatively affect students' academic performance (Jacoby, 2005). Assistant professors who seek promotion may make greater effort for research than for teaching, compared to associate or full-time professors who hold a tenure-track position at the university. This could also damage the quality of teaching, as stated by García-Gallego et al. (2012). For this reason, we include in our model the dummy variables afprofessor, aprofessor and alecturer, which have the value of 1 if the professor works as a full or associate professor, assistant professor or adjunct lecturer, and 0 if not.

Instructors in each category may have spent a different number of years teaching in the university. Professors with more work experience may spend less time on preparing a class than those with less experience, which could be due to a learning and experience effect on the instructor (Tien \& Balckburn, 1996). To assess this, our model includes the variable experience which represents the number of years from the beginning of his/her academic career until the start of each course.

The learning and experience effect also exists when the instructor has to prepare the same subject during the academic year, instead of preparing two or more subjects, which may affect their lectures. For this reason, in this model, we will take into account the workloadp variable, which represents the percentage number of hours taught by the professor on the Financial Accounting course out of his/her total number of hours worked during the academic year.

Professors who spend their teaching time on preparing only one subject may deliver higher quality teaching, which can lead to greater student learning (Riehl \& Sipple, 1996). In order to examine the effect of the quality of teaching on students' academic performance, we introduce the qteaching variable as a proxy, assessing it with students' evaluations of teaching based on a standard university survey (with a scale of 0 to 4). To assess each instructor's performance, the university chooses the courses where it carries out the teaching evaluations survey at random, given that the university is not able to assess all courses in which professors teach, due to lack of financial and/or human resources. Instructors do not know in which subjects the teaching evaluation survey will be conducted. This survey is conducted before students take their final exams. The professor knows the scores of the students' teaching evaluations in the following academic year. This allows us to reduce the biases detected by Ewing (2012).

Moreover, students may assess instructors of the same gender better in the teaching evaluations survey, which may be due to the Pygmalion effect or the 
role-model effect (Cho, 2012). For this reason, a dummy variable samegen will be introduced, having a value of 1 if the student is of the same gender as the instructor and 0 if not.

To measure the quality of research productivity, we will use the number of articles published in highly ranked international peer-reviewed journals in the ISI Web of (Social) Science and Econlit databases, during the three academic years following the current course, and denoted referred.

Given that Mishra and Smith (2012) indicate that these databases are insufficient to assess the performance of scholars in the area of social sciences, Harzing (2013) suggests the use of Google Scholar to measure the quantity of research published by each instructor. For this reason, we will include in our model the nonrefer variable, which represents the number of books and articles in journals not included in the ISI Web of Science and Econlit databases during the three academic years following the current course.

The control variables used in this work are often used in literature regarding academic performance (Cantwell et al., 2001; Marcenaro \& Navarro, 2007; Martí, 2012; McKenzie \& Schweitzer, 2001; Sheard, 2009; Martí \& Orgaz, 2014). They include age, student's gender, degree, grant, number of times the student has enrolled in the subject, ability and pre-university studies specialization. The descriptive statistics and first-order correlations between independent variables and control variables are shown in table 1 and 2, respectively. Table 2 indicates that the variance inflation factor (VIF) values for each variable are between 1.07 and 8.82. This suggests that each independent variable has a VIF between 1 and 10. Therefore, no multicollinearity problems exist (Sharma \& James, 1981). 
Table 1. Measurement of dependent and independent variables

\begin{tabular}{|c|c|}
\hline Variable & Measure \\
\hline \multicolumn{2}{|l|}{ Dependent } \\
\hline Result for student & Total result for student for exam and assessment items \\
\hline \multicolumn{2}{|l|}{ Independent } \\
\hline qteaching & Students' evaluations of teaching taking values between 0 and 4 . \\
\hline workloadp & $\begin{array}{l}\text { Percentage number of hours taught by the professor on the Financial } \\
\text { Accounting subject. }\end{array}$ \\
\hline admduties & $\begin{array}{l}1=\text { the instructor carries out administrative tasks during academic } \\
\text { years; } 0=\text { does not have administrative tasks during the academic } \\
\text { year }\end{array}$ \\
\hline afprofessor & $\begin{array}{l}1=\text { the professor works as a full-time or associate professor; } 0=\text { did } \\
\text { not work as full-time or associate professor }\end{array}$ \\
\hline aprofessor & $\begin{array}{l}1=\text { the professor works as an assistant professor; } 0=\text { did not work } \\
\text { as an assistant professor. }\end{array}$ \\
\hline experience & Number of years from the beginning of his academic career. \\
\hline referred & $\begin{array}{l}\text { Number of articles published in highly ranked international peer- } \\
\text { reviewed journals. }\end{array}$ \\
\hline nonrefer & $\begin{array}{l}\text { Number of books and articles in journals not included in the ISI } \\
\text { Web of Science. }\end{array}$ \\
\hline age & Indicates the age of the student in years. \\
\hline gender & $1=$ male $; 0=$ female \\
\hline grant & $1=$ grant; $0=$ no grant \\
\hline business/social & $\begin{array}{l}\text { 1=studied the specialisation indicated in secondary education: } 0 \\
=\text { did not study it. }\end{array}$ \\
\hline entrance & University entrance exam grade (5-10 points). \\
\hline credits & $\begin{array}{l}\text { Number of credits the student has passed during the year minus } \\
\text { the credits passed in the subject of Financial Accounting. }\end{array}$ \\
\hline repeat & $1=$ repeat; $0=$ no repeat \\
\hline degress & $1=$ studying the academic degree indicated; $0=$ is not studying it. \\
\hline afternoon & $\begin{array}{l}1=\text { the student attends class in the afternoon; } 0=\text { the student at- } \\
\text { tends class in the morning. }\end{array}$ \\
\hline size & Number of students making up a group. \\
\hline
\end{tabular}


More experienced professors, more learning opportunities? Relationships between instructor's traits and students' academic performance in ...

Table 2: Correlation Matrix for Regression Variables

\begin{tabular}{|c|c|c|c|c|c|c|c|c|}
\hline & vif & qteaching & workloadp & admduties & afprofessor & aprofessor & experience & referred \\
\hline qteaching & 3.24 & 1 & & & & & & \\
\hline workloadp & 2.53 & 0.249 & 1 & & & & & \\
\hline admduties & 6.08 & 0.084 & -0.153 & 1 & & & & \\
\hline afprofessor & 8.82 & -0.263 & -0.402 & 0.789 & 1 & & & \\
\hline aprofessor & 8.28 & 0.052 & -0.214 & -0.109 & -0.251 & 1 & & \\
\hline experience & 2.82 & -0.153 & -0.072 & 0.444 & 0.403 & 0.099 & 1 & \\
\hline referred & 4.18 & -0.118 & -0.178 & 0.116 & 0.142 & 0.651 & -0.006 & 1 \\
\hline nonrefer & 5.48 & 0.025 & -0.297 & 0.406 & 0.273 & 0.680 & 0.256 & 0.678 \\
\hline samegen & 1.30 & 0.067 & 0.131 & -0.055 & -0.096 & -0.055 & -0.044 & -0.052 \\
\hline age & 1.33 & 0.125 & 0.140 & -0.111 & -0.122 & -0.173 & -0.087 & -0.152 \\
\hline gender & 1.37 & -0.019 & 0.084 & -0.021 & 0.015 & -0.167 & -0.014 & -0.106 \\
\hline grant & 1.14 & -0.079 & -0.094 & 0.088 & 0.067 & 0.117 & 0.081 & 0.102 \\
\hline repeat & 1.54 & 0.223 & 0.258 & -0.219 & -0.246 & -0.220 & -0.164 & -0.238 \\
\hline business & 1.07 & -0.027 & -0.006 & -0.026 & -0.030 & 0.006 & -0.017 & -0.006 \\
\hline social & 1.15 & -0.004 & -0.069 & 0.027 & 0.019 & 0.081 & 0.035 & 0.035 \\
\hline entrance & 1.80 & 0.008 & -0.236 & 0.050 & -0.050 & 0.437 & 0.012 & 0.313 \\
\hline credits & 1.42 & 0.085 & -0.129 & 0.096 & 0.010 & 0.335 & 0.100 & 0.255 \\
\hline degree & 2.91 & -0.001 & -0.352 & -0.085 & -0.224 & 0.560 & -0.131 & 0.277 \\
\hline year2005 & 2.75 & -0.162 & -0.351 & -0.007 & 0.184 & -0.027 & -0.088 & -0.086 \\
\hline year2006 & 2.37 & 0.114 & 0.011 & -0.039 & -0.061 & -0.048 & -0.063 & -0.214 \\
\hline year2007 & 2.19 & 0.061 & 0.096 & -0.037 & -0.059 & -0.017 & 0.077 & 0.016 \\
\hline afternoon & 2.08 & 0.092 & 0.202 & -0.247 & -0.262 & -0.355 & -0.051 & -0.345 \\
\hline size & 5.44 & -0.531 & 0.094 & -0.268 & -0.080 & -0.310 & 0.278 & -0.415 \\
\hline
\end{tabular}

Source: Own work 
Table 2: Cont.

\begin{tabular}{|l|c|c|c|c|c|c|c|}
\hline & nonrefer & samegen & age & gender & grant & repeat & business \\
\hline nonrefer & 1 & & & & & & \\
\hline samegen & -0.097 & 1 & & & & & \\
\hline age & -0.200 & 0.093 & 1 & & & & \\
\hline gender & -0.110 & 0.452 & 0.103 & 1 & & & \\
\hline grant & 0.142 & -0.069 & -0.163 & -0.149 & 1 & & \\
\hline repeat & -0.313 & 0.075 & 0.338 & 0.071 & -0.288 & 1 & \\
\hline business & -0.011 & -0.029 & 0.082 & -0.033 & 0.051 & -0.052 & 1 \\
\hline social & 0.061 & -0.091 & -0.257 & -0.162 & 0.121 & -0.059 & -0.155 \\
\hline entrance & 0.328 & -0.055 & -0.189 & -0.189 & 0.141 & -0.293 & 0.089 \\
\hline credits & 0.290 & -0.033 & -0.224 & -0.142 & 0.131 & -0.288 & -0.033 \\
\hline degree & 0.257 & -0.059 & -0.128 & -0.176 & 0.099 & -0.153 & 0.066 \\
\hline year2005 & -0.043 & 0.005 & 0.023 & -0.008 & -0.028 & 0.018 & -0.057 \\
\hline year2006 & -0.097 & -0.011 & -0.012 & -0.005 & -0.019 & -0.045 & 0.017 \\
\hline year2007 & -0.183 & -0.010 & 0.014 & -0.007 & -0.010 & 0.008 & 0.028 \\
\hline afternoon & -0.407 & 0.061 & 0.343 & 0.070 & -0.119 & 0.305 & 0.062 \\
\hline size & -0.421 & 0.013 & 0.116 & 0.086 & -0.034 & 0.175 & 0.023 \\
\hline
\end{tabular}

Source: Own work

Table 2: Cont.

\begin{tabular}{|l|c|c|c|c|c|c|c|c|}
\hline & social & entrance & credits & degree & year2005 & year2006 & year2007 & afternoon \\
\hline social & 1 & & & & & & & \\
\hline entrance & 0.067 & 1 & & & & & & \\
\hline credits & 0.027 & 0.434 & 1 & & & & & \\
\hline degree & 0.106 & 0.574 & 0.301 & 1 & & & & \\
\hline year2005 & -0.014 & -0.033 & -0.026 & -0.025 & 1 & & & \\
\hline year2006 & 0.002 & -0.013 & -0.040 & 0.002 & -0.335 & 1 & & \\
\hline year2007 & 0.013 & 0.004 & 0.042 & 0.017 & -0.341 & -0.321 & 1 & \\
\hline afternoon & -0.131 & -0.182 & -0.199 & -0.080 & -0.025 & -0.002 & -0.016 & 1 \\
\hline size & -0.058 & -0.225 & -0.264 & -0.187 & 0.257 & -0.183 & -0.095 & 0.440 \\
\hline
\end{tabular}

Source: Own work 


\section{Data analysis}

We use a censored least absolute deviations regression model proposed by Powell $(1984)^{1}$, which does not require known distributional form in the term error, to analyse whether the characteristics of instructors influence the academic success of students. It is defined as follows:

$$
\begin{array}{lll}
y_{i}^{*}=\alpha+\beta^{1} x_{i}+u_{i} & \text { si } & y<y_{i}^{*}<\bar{y} \\
y_{i}^{*}=\bar{y} & \text { si } & y_{i}^{*}>\bar{y} \\
y_{i}^{*}=\bar{y} & \text { si } & y_{i}^{*}<\bar{y}
\end{array}
$$

Where $y i^{*}$ is the academic performance reached by the undergraduate; y represents the minimum amount of points that a student can obtain ( 0 points); $\bar{y}$ is the maximum score that a student can reach (10 points); $x i$ is a vector that contains all the explanatory variables of students' academic performance; $\boldsymbol{\beta}$ is a K-dimensional vector of unknown parameters; $u i$ are the residuals which do not require known distributional form, as shown by Powell (1984). The standard errors of the estimations were obtained using the bootstrap technique.

\section{Results}

The results obtained by estimating the censored least absolute deviations model are shown in table 3 . These results show that the qteaching variable is positively and significantly associated with student's academic performance. Other factors held constant, a 1 point increase in the teaching evaluation is associated with a 0.90 point rise in the students' academic performance. This result is consistent with Jacob and Lefgren (2008), Hoffmann and Oreopoulos (2009) and Beleche et al. (2012), demonstrating that teaching evaluations are a good indicator of the quality of teaching. Thus, students attending Financial Accounting classes given by instructors with more highly evaluated teaching might achieve better academic performance than those who attend classes given by professors with lower teaching evaluations.

1 Unlike the Tobit maximum likelihood estimator proposed by Tobin (1958), the censored least absolute deviations model provides robust and consistent estimators in presence of non-normality and heteroscedasticity of the error terms (Powell, 1984). Given that the results obtained implementing likelihood ratio test (LR=309.44; $\mathrm{p}$-value $=0.000$ ) and the conditional moment test (conditional moment $=135.60 ; \mathrm{p}$-value: 0.000$)$ indicate the presence of heteroscedasticity and non-normality in the model, the clad model proposed by Powel (1984) was adopted. 
Table 3: Academic performance

\begin{tabular}{|c|c|c|c|}
\hline \multirow{3}{*}{$\begin{array}{c}\text { Variable } \\
\text { qteaching }\end{array}$} & \multicolumn{3}{|c|}{$C L A D$} \\
\hline & \multicolumn{2}{|c|}{$\begin{array}{c}\text { Coefficient } \\
\text { (及) }\end{array}$} & \multirow{2}{*}{$\begin{array}{c}\text { Standard } \\
\text { Error } \\
0.2841\end{array}$} \\
\hline & 0.8986 & $* * *$ & \\
\hline workloadp & -0.0128 & $* *$ & 0.0054 \\
\hline admduties & -0.2274 & & 0.4358 \\
\hline afprofessor & 0.5956 & & 0.4587 \\
\hline aprofessor & -0.8141 & $* *$ & 0.3540 \\
\hline experience & 0.3119 & & 0.6083 \\
\hline experience ${ }^{\wedge} 2$ & -0.3178 & * & 0.1852 \\
\hline referred & 0.2530 & * & 0.1418 \\
\hline nonrefer & 0.0349 & & 0.0949 \\
\hline samegen & -0.0251 & & 0.1284 \\
\hline age & -0.0386 & & 0.0741 \\
\hline gender & -0.1231 & & 0.1274 \\
\hline grant & 0.3742 & $* * *$ & 0.1305 \\
\hline repeat & 0.7172 & $* * *$ & 0.2132 \\
\hline business & 2.0679 & $* * *$ & 0.5359 \\
\hline social & 0.2878 & * & 0.1425 \\
\hline entrance & 0.6469 & $* * *$ & 0.0873 \\
\hline credits & 0.1097 & $* * *$ & 0.0038 \\
\hline degree & 0.3758 & & 0.2289 \\
\hline afternoon & -1.1398 & $* * *$ & 0.2509 \\
\hline size & 0.0465 & $* * *$ & 0.0086 \\
\hline year2005 & -0.5597 & $* *$ & 0.2694 \\
\hline year2006 & -0.5043 & * & 0.2822 \\
\hline year2007 & -0.7491 & $* * *$ & 0.2463 \\
\hline Constant $(\alpha)$ & -9.0021 & $* * *$ & 2.4201 \\
\hline N. observations & 3,219 & & \\
\hline Left-Censured & 1,134 & & \\
\hline Right-Censured & 1 & & \\
\hline Pseudo R & 0.2472 & & \\
\hline
\end{tabular}

Statistical significance at the $1 \%, 5 \%$ and $10 \%$ levels is denoted by *** **, *, respectively. 
On the other hand, we find a significant and negative relationship between the workloadp variable and student's academic performance. Other factors held constant, a 1 point increase in the WORKLOADP variable is associated with a 0.01 point decrease in the students' academic performance. This indicates that the professors taking different subjects in the accounting area are able to transmit better knowledge to students and present the key concepts from a wider perspective on the accounting area. Therefore, professors teaching several subjects could use the content of other subjects to explain financial accounting and/or resolve doubts among students of this subject.

Our estimates also suggest that other factors held constant: an increase in the percentage of assistant professors with respect to adjunct lecturers, is associated with a significant reduction in students' academic performance; while a modification in the relationship between the percentages of full or associate professors and adjunct lecturers does not significantly influence student success. Thus, congruent with Tien and Blackburn (1996), Faculty members of higher rank deploy more effective teaching than those in lower ranks who might be putting more effort into increasing their productivity in research in order to gain promotion and obtain tenure positions, according to Chow and Harrison (1998). On the other hand, adjunct lecturers are specialized in teaching and have concurrent employment in the private sector, which enables them to explain their experiences in private companies to students, thus improving their academic performance, as suggested by Bettinger and Long (2010).

We also find a nonlinear relationship between the experience variable and students' academic performance, which is summarized by the positive coefficient of the linear term and the negative and significant coefficient of the square term. This suggests that students' academic performance is positively affected by attending classes given by experienced professors until a maximum is reached, beyond which higher levels of experience may hinder the students' academic performance. This finding could be due to: (1) The most experienced professors within each rank being less motivated, which leads to a reduction in their student's academic performance; And/or (2) the existence of assistant professors whose contracts are about to end, meaning that they spend more time on research activities and less time on teaching activities because in evaluation processes for promotion of individual Faculty members, the Spanish State System and Spanish universities give greater weight to articles published in journals indexed in the ISI Web of Science than to teaching effectiveness. This is consistent with Barnett (1992), Chow and Harrison (1998), and Hardre et al, (2011).

Our estimates suggest that other factors held constant, an increase in the number of articles by the instructor published in journals indexed in the ISI Web 
of Science and Econlit databases is associated with an increase in students' academic performance. Each additional article published by a professor is associated with a 0.26 point rise in students' academic performance. This could be due to professors doing research in issues related to class content, allowing them to give more detailed lectures, or having more extensive knowledge of the accounting area. This result is congruent with García-Gallego et al. (2012) and Witte et al. (2013), revealing that teaching effectiveness and quality research are complementary in the accounting area, there being synergies and economies of scope between research and teaching activities.

Regarding control variables for the individual characteristics of students and institutions, we find that the effect of obtaining study grants on students' academic performance is positive and significant. Thus, the academic performance of students benefiting from grants is on average 0.37 points higher than that of students who do not receive study grants. This could be because students receiving grants during their first year in university come from humble families which need a grant in order for the student to continue their studies. Therefore, they are more motivated to achieve their aim, which is to obtain a good academic record so that they can have their grant renewed. This is consistent with Marcenaro and Navarro (2007).

Our results also reveal that the repeat variable is positively and significantly associated with student's academic performance. The students who did not manage to pass the Financial Accounting credits in previous exams, increase their academic performance by 0.72 points compared to new entrants, other factors held constant. This may be due to the fact that the student is more familiar with the material and the type of exam given in the subject.

Obtaining a good academic record proves to be significantly more feasible for those students who previously studied accounting in vocational training Higher Education courses in Administration and Finance (BUSINESS variable) than for their classmates coming from the Social Science (SOCIAL variable), specialisation in secondary school or other secondary education studies, which could point to the existence of a close correspondence between secondary school and university curricula. This result is consistent with the empirical evidence provided by Eskew and Faley (1988) and Martí (2012).

We also find that the variable entrance seems to influence significantly and positively students' academic performance. Thus, students who achieve higher university entrance grades obtain a better academic performance than those who achieve poor university entrance grades. More specifically, a 1 point increase in the university entrance grade means an increase of approximately 0.65 points in the academic performance in the subject of Financial Accounting. Such result is consistent with previous studies carried out by Kherfi (2008) and Martí (2012). 
The effort made by students during the year, measured using the variable credits, also seems to have a positive and significant influence on student's academic performance. Thus, those students who passed a greater number of credits during the year obtained a better academic performance. The time at which students attend class significantly influences their academic performance. In this regard, students who attend class in the afternoon obtain approximately 1.14 points less in their academic performance than those students who attend class in the morning. This result contradicts the empirical evidence encountered by Kherfi (2008), which may be because the morning timetable established by the Universitat Autònoma de Barcelona starts at an attractive time for students (9.00 to 10.00 in the morning). Those students who have better academic records can choose the morning time-slot, while students who work may be more interested in attending classes in the afternoon, combining professional obligations with academic responsibilities, which may result in poorer academic performance since they have less time to carry out the exercises given in class.

On the contrary, empirical evidence was fount that class size has a positive and significant influence on the students' academic performance. This could be due to the fact that the professor feels more motivated and prepares the classes better when giving a lecture to a large number of students. This would improve the teaching and the academic performance of students.

Finally, the present results show that the academic year in which students take the Financial Accounting course significantly affects students' academic performance. This could be due to differences in the difficulty level of exams, the exams in the last year (2008/2009 academic course) being easier because of an imminent change in Spanish accounting rules.

\section{Discussion and conclusion}

This paper contributes to an increasing body of literature examining the factors that influence students' academic performance. While other studies focus on analysing how students and institutional characteristics affect students' success, our study examines how professors' characteristics exert a differential impact on students' academic performance. The findings, combined with other studies, may prove to be useful in Accounting Education and other professional programs in Higher Education.

According to this, the results show that quality of teaching and publishing more articles in journals indexed in the ISI Web of Science and Econlit databases have a positive and significant influence on students' academic performance. On the contrary, dedicating more lecture time to Financial Accounting with regard to the total number of hours taught, working as an adjunct professor and having more teaching experience negatively influence students' academic performance. 
Students attending Financial Accounting classes taught by assistant professors achieve poorer academic performance than those who attend classes taught by adjunct lecturers, associate professors or full-time professors, probably because assistant professors spend more time on research activities and less time on teaching activities in order to gain promotion to tenured track positions, the Ministry of Education and Research and the universities should: (1) Reduce the number of hours taught by assistant professors for them to achieve associate professor status, from which students will benefit, or (2) Assign teaching assistants to classes given by assistant professors.

It was also possible to detect poorer academic performance among students that attend classes given by more experienced professors, which could be because more experienced associate professors, full-time professors and adjunct lecturers are unmotivated because they are near retirement, while more experienced assistant professors make more effort into their research activities because their promotion is imminent. To improve their teaching effectiveness, the Ministry of Education and Research and the universities could reduce the number of teaching hours or give professors a year's sabbatical, depending on the number of years they have been teaching.

On the other hand, the quality of research is a relevant factor in students' academic performance. For this reason, the Ministry of Education and Research and the universities should encourage research by: (1) Increasing the salary incentives based on the number of articles published in leading journals while reducing their base salary and other complements; and (2) Giving research grants to assistant professors in order for them to be able to do research and gain promotion to associate professor positions. As commented by Martí (2012), it was also found that the individual characteristics of students and institutions affect their own academic performance.

Regarding the limitations of this work, the empirical evidence provided (although potentially important) may have a limited validity, as the students in this study were from the Business and Economics programs, enrolled in one single university, the Universitat Autònoma de Barcelona. Therefore, it is difficult to generalize results to other areas, degrees and universities which may have little relation. Nevertheless, it is possible to assume that the sample used could be representative of students who enrol in Financial Accounting courses in State, public and large universities. For future studies, it may be useful to analyse the impact of professors' characteristics on students' academic performance using student samples from other disciplines and/or other universities, comparing the results obtained by public and private universities. 


\section{References}

Adler, Nancy J., and Anne-Wil Harzing. (2009). When knowledge wins: Transcending the sense and nonsense of academic ranking. Academy of Management Learning and Education, V. 8, n 1, pp. 72-95.

Angrist, Joshua D., and Victor Lavy (2001). Does teacher training affect pupil learning? Evidence from matched comparisons in Jerusalem public schools. Journal of Labor Economics, V. 19, nº 2, pp. 343-369.

Armstrong, David, and Peter Goodyear. (2006). Implications of external research quality assessment for local research leadership: Learning from the UK RAE experience. Australian Educational Researcher, $\mathrm{n}^{\circ} 33, \mathrm{pp} .19-41$.

Arnold, Ivo J.M. (2008). Course level and the relationship between research productivity and teaching effectiveness. Journal of Economic Education, V. 39, n 4, pp. 307-321.

Barnett, Bryan. (1992). Teaching and research are inescapably incompatible. Chronicle of Higher Education, p. A40.

Bazeley, Pat. (2003). Defining early career in research. Higher Education, V. 45, nº 3, pp. 257-279.

Becker, William E., and John R. Powers. (2001). Student performance, attrition, and class size given missing student data. Economics of Education Review, V. 20, nº 4, pp. 377-388.

Bedard, Kelly, and Peter Kuhn. (2008). Where class size really matters: class size and student ratings of instructor effectiveness. Economics of Education Review, V. 27, n 3, pp. 253-265.

Beleche, Trinidad, David Fairris, and Mindy Marks. (2012). Do course evaluations truly reflect student learning? Evidence from an objectively graded post-test. Economics of Education Review, V. 31, n 5 , pp. 709-719.

Benjamin, Ernst. (2002). How over reliance upon contingent appointments diminishes faculty involvement in student learning. Peer Review, V. 5, n 1, pp. 410.

Benjamin, Ernst. (2003). Reappraisal and Implications for Policy and Research. New Directions for Higher Education, $n^{\circ} 123$, pp. 79-113.

Bettinger, Eric P., and Bridget Terry Long. (2010). Does cheaper mean better? The impact of using adjunct instructors on student outcomes. Review of Economics and Statistics, V. 92, n 3, pp. 598-613.

Braxton, John M. (1996). Contrasting perspectives on the relationship between teaching and research. New Directions for Institutional Research, n 90, pp. 5-14.

Cantwell, Robert, Jennifer Archer, and Sid Bourke. (2001). A comparison of the academic experiences and achievement of university students entering by traditional and non-traditional means. Assessment and Evaluation in Higher Education, V. 26, n 3, pp. 221-234.

Carrell, Scott E., and James E. West. (2010). Does Professor Quality Matter? Evidence from Random Assignment of Students to Professors. Journal of Political Economy, V. 118, n 3, pp. 409-432.

Cherchye, Laurens, Bram De Rock, and Frederic Vermeulen. (2008). Analyzing cost-efficient production behavior under economics of scope: A nonparametric methodology. Operations Research, V. 56, $n^{\circ} 1$, pp. 204-221.

Cho, Insook. (2012). The effect of teacher-student gender matching: Evidence from oecd countries. Economics of Education Review, V. 31, n 3, pp. 54-67.

Chow, Chee W., and Paul Harriso. (1998). Factors contributing to success in research and publications: Insights of "influential" accounting authors. Journal of Accounting Education, V. 16, nº 3-4, pp. 463-472. 
Dobbie, Will. (2011). Teacher characteristics and student achievement: evidence from Teach for America. Working Paper. Harvard University. En: https://www.princeton.edu/ wdobbie/files/dobbie _tfa_2011. pdf

Eskew, Robert K., and Robert H. Faley. (1988). Some determinants of student performance in the first college level financial accounting course. The Accounting Review, V. 63, nº 1, pp. 137-147.

Ewing, Andrew M. (2012). Estimating the Impact of Relative Expected Grade on Student Evaluations of Teachers. Economics of Education Review, V. 31, n 1, 141-154.

Fairweather, James S. (2002). The mythologies of faculty productivity: Implications for institutional policy and decision-making. Journal of Higher Education, V. 73, nº 1, pp. 26-48.

Fogarty, Timothy J. (2004). Sustained research productivity in accounting: a study of the senior cohort. Global Perspectives on Accounting Education, V. 1, pp. 31-58.

García-Gallego, Aurora, Nikolaos Georgantzís, Joan Martín-Montaner, and Teodosio Perez Amaral. (2012). How do research and administrative duties affect university professors' teaching? Available at ssrn: http://dx.doi.org/10.2139/ssrn.2133898

Gibbs, Graham, and Martin Coffey. (2004). The impact of training of university teachers on their teaching skills, their approach to teaching and the approach to learning of their students. Active Learning in Higher Education, V. 5, n 1, pp. 87-100.

Goodwin, Thomas H., and Raymond D. Sauer. (1995). Life cycle productivity in academic research: Evidence from cumulative publication histories of academic economists. Southern Economic Journal, V. $61, n^{\circ} 3$, pp. $728-743$.

Hardré, Patricia L., Andrea D. Beesley, Raymond L. Miller, and Terry M. Pace. (2011). Faculty motivation to do research: across disciplines in research extensive universities. The Journal of the Professoriate, V. 5, n 1 , pp. 35-69.

Harris, Douglas N., and Tim R. Sass. (2011). Teacher training, teacher quality and student achievement. Journal of Public Economics, V. 95, n 7, pp. 798-812.

Harzing, Anne-Wil. (2013) A Preliminary Test of Google Scholar as a Source of Citation Data: A Longitudinal Study of Nobel Prize Winners, Scientometrics, V. 94, nº 3, pp. 1057-1075.

Hattie, John, and Herbert W. Marsh. (1996). The relationship between research and teaching-a metaanalysis. Review of Educational Research, V. 66, n 4, pp. 507-542.

Hemmings, Brian, and Russell Kay. (2008). Lecturer self-efficacy, research skills, and publication output. Paper presented at the Australian Association for Research in Education (aare) Conference, Brisbane, Australia. Available at: http://www.aare.edu.au/08pap/hem08131.pdf

Hoffmann, Florian, and Philip Oreopoulos. (2009). Professor qualities and student achievement. The Review of Economics and Statistics, V. 91, n 1, pp. 83-92.

Hu, Qing, and T. Grandon Gill. (2000). Is faculty research productivity: Influential factors and implications. Information Resources Management Journal, V. 13, n 2, pp. 15-25.

Jacob, Brian A., and Lars Lefgren. (2008). Principals as agents: subjective performance measurement in education. Journal of Labour Economics, V. 26, nº 1, pp. 101-136.

Jacoby, Daniel. (2005). Part-time or contingent community college faculty and the desire for full-time tenure track positions. Community College Journal of Research and Practice, V. 29, pp. 1-16.

Jacoby, Daniel. (2006). Effects of Part-Time Faculty Employment on Community College Graduation Rates. The Journal of Higher Education, V. 77, $n^{\circ}$ 6, pp. 1081-1103. 
Jaeger, Audrey J., and M. Kevin Eagan. (2011). Examining Retention and Contingent Faculty Use in a State System of Public Higher Education. Educational Policy, V. 25, n 3, pp. 507-537.

Kennedy, Peter E., and John J. Siegfried. (1997). Class size and achievement in introductory economics: evidence from the tuce iii data. Economics of Education Review, V. 16, nº 4, pp. 385-394.

Kherfi, Samer. (2008). Economic Education in the Middle East: Are the Determinants of Success in Introductory Economics Any Different? Journal of Economic Education, V. 39, n 1, pp. 22-40.

Kim, Seongsu. (2003). The impact of research productivity on early retirement of university professor. Industrial Relations, V. 42, n 1, pp. 106-125.

Levin, Sharon G., and Paula E. Stephan. (1991). Research productivity over the life cycle: evidence for academic scientist. American Economic Review, V. 81, n 1, pp. 114-132.

Lindbeck, Assar, and Dennis J. Snower. (2003). The Firm as a Pool of Factor Complementarities. iza Discussion Paper 882.

McKenzie, Kirsten, and Robert Schweitzer. (2001). Who succeeds at university? Factors predicting academic performance in first year Australian university students. Higher Education Research \& Development, V. 20, n 1, pp. 21-33.

Marcenaro Gutiérrez, Oscar D., and María Navarro Gómez. (2007). El éxito en la universidad: una aproximación cuantílica. Revista de Economía Aplicada, V. 15, nº 44, pp. 5-39.

Marsh, Herbert W., and John Hattie. (2002). The relation between research productivity and teaching effectiveness: complementary, antagonistic or independent constructs? The Journal of Higher Education, V. $73, n^{\circ} 5$, pp. 603-641.

Martí-Ballester, Carmen-Pilar. (2012). Analysis of the Factors that Influence the Academic Performance of Financial Accounting Students using Binary Choice Models. Review of Business Management, V. 14, $\mathrm{n}^{\circ} 45$, pp. 379-399.

Martí-Ballester, Carmen-Pilar, and Neus Orgaz-Guerrero. (2014). Análisis del uso de cuestionarios en contabilidad financiera. Educación XX1, V. 17, n 1, pp. 271-290.

Massy, William F., and Andrea K. Wilger. (1995). Improving productivity: What faculty thinks about it-and its effect on quality. Change, V. 27, $n^{\circ} 4$, pp. 10-20.

Mishra, Vinod, and Russell Smyth. (2012). Are more senior academics really more research productive than junior academics? Evidence from Australian law schools. Scientometrics, (In press).

Neumann, Ruth. (1992). Perceptions of the teaching-research nexus: A framework for analysis. Higher Education, V. 23, nº 2, pp. 159-171.

Noser, Thomas C., Herman Manakyan, and John R. Tanner. (1996). Research Productivity and Perceived Teaching Effectiveness: A Survey of Economics Faculty. Research in Higher Education, V. 37,n 3, pp. 299-321.

Powell, James L. (1984). Least Absolute Deviations Estimation for the Censored Regression Model. Journal of Econometrics, V. 25, n 3, pp. 303-325.

Prince, Michael J., Richard M. Felder, and Rebecca Brent. (2007). Does faculty research improve undergraduate teaching? An analysis of existing and potential synergies. Journal of Engineering Education, V. 96, n 4, pp. 283-294.

Ramsdem, Paul. (1998). Managing the effective university. Higher Education Research and Development, V. $17, n^{\circ} 3$, pp. 347-371. 
Ramsden, Paul, and Ingrid Moses. (1992). Association between research and teaching in Aus-tralian higher education. Higher Education, V. 23, n 3, pp. 273-295.

Riehl, Carolyn, and John W. Sipple. (1996). Making the Most of Time and Talent: Secondary School Organizational Climates, Teaching Task Environments, and Teacher Commitment. American Educational Research Journal, V. 33, n4, pp. 873-901.

Sharma, Subhash, and William L. James. (1981). Latent root regression: An alternate procedure for estimating parameters in the presence of multicollinearity. Journal of Marketing Research, V. 18, $n^{\circ}$ 2, pp.154-161.

Sheard, Michael. (2009). Hardiness commitment, gender, and age differentiate university academic performance. British Journal of Educational Psychology, V. 79, nº 1, pp. 189-204.

Spiller, Pablo T., and Bennet A. Zelner. (1997). Product Complementarities, Capabilities and Governance: A Dynamic Transaction Cost Perspective. Industrial and Corporate Change, V. 6, nº 3, pp. 561-594.

Sullivan, Anna V. Shaw. (1996). Teaching norms and publication productivity. New Directions for Institutional Research, $n^{\circ}$ 90, pp. 15-21.

Sykes, Pat. (2006). Working in a 'new' university: In the shadow of the Research Assessment Exercise. Studies in Higher Education, V. 31, n 5, pp. 555-568.

Stack, Steven. (2003). Research productivity and student evaluation of teaching in social science classes: a research note. Research in Higher Education, V. 44, n 5 , pp. 539-556.

Tien, Flora F., and Robert T. Blackburn. (1996). Faculty rank system, research motivation, and faculty research productivity: Measurement refinement and theory testing. Journal of Higher Education, V. 67, n 1, pp. 2-22.

Tobin, James (1958). Estimation of relationships for limited dependent variables. Econometrica: journal of the Econometric Society, V. 26, no 1, pp. 24-36.

Toutkoushian, Robert Kevin, and Marcia L. Bellas. (1999). Faculty time allocations and research productivity. The Review of Higher Education, V. 22, n 4, pp. 367-390.

Umbach, Paul D. (2007). How effective are they? Exploring the impact of contingent faculty on undergraduate education. The Review of Higher Education, V. 30, n 2, pp. 91-124.

Walstad, William B. (2001). Improving assessment in University Economics, Journal of Economic Education, V. 32, n 3, pp. 281-294.

Watty, Kim, Sheila Bellamy, and Clive Morley. (2008). Changes in higher education and valuing the job: The views of accounting academics in Australia. Journal of Higher Education Policy and Management, V. $30, n^{\circ} 2$, pp. 139-151.

Witte, Kristof, Nicky Rogge, Laurens Cherchye, and Tom Van Puyenbroeck. (2013). Economies of scope in research and teaching: a non-parametric investigation. Omega, V. 41, n ${ }^{\circ}$, pp. 305-314. 